\title{
Foreign Unit Strategic Decision Making Process
}

\author{
Yezdi H. Godiwalla ${ }^{1}$ \\ ${ }^{1}$ Management Department, College of Business and Economics, University of Wisconsin-Whitewater, Whitewater, \\ USA \\ Correspondence: Yezdi H. Godiwalla, Professor, Management Department, College of Business and Economics, \\ University of Wisconsin-Whitewater, Whitewater, WI, 53190-1790, USA. \\ Received: July 4, 2016 \\ doi:10.5430/jms.v7n3p1 \\ Accepted: July 19, 2016 \\ Online Published: August 17, 2016 \\ URL: http://dx.doi.org/10.5430/jms.v7n3p1
}

\begin{abstract}
A foreign subsidiary unit of a multinational corporation (MNC) goes through evolutionary stages as it grows in its host country environment. For each stage of its evolutionary process, there are specific challenges and expectations of which its top management must be fully aware in order to succeed in its decision making and action. The foreign subsidiary unit's top management must analyze its performance expectations and performance criteria, as set by the MNC's corporate headquarters, home and host countries' stakeholders, in order to be effective in managing the foreign subsidiary unit.
\end{abstract}

Keywords: foreign subsidiary strategic management, international strategic management

\section{Introduction}

Colonial subjugation never lasts. The cruel method of the Roman Empire to punish unwieldy societies eventually released from under its yoke its colonized societies. The British Empire, not withstanding its claim to superiority, similarly dismembered and ceased. No subjugated society, however weak or backward, can trail in its race for self determination. As for the former British Empire, the largest remaining colony is the Nassau which has some 80,000 residents.

Multinational corporations (MNCs) must not pursue strategic and operational subjugation of its foreign units. An MNC's headquarters must go beyond operational empowerment of it's (wholly or partially-owned) foreign units. It must also prepare them to increasingly acquire strategic capability over and above substantial operational autonomy.

\section{Purposes of the Paper}

A foreign subsidiary unit, nested in the context of its host country environment, goes through different stages of organizational evolution: (1) entrepreneurial or start-up, (2) growth and collectivity, (3) formalization or large scale structuring, and (4) sprawling elaboration. It must select effective strategies that would correctly focus upon the unique challenges of each stage.

This paper provides challenges and conditions that can be expected during each stage of the foreign unit's organizational development. Further, the paper proposes the likely effective approaches to meet with the challenges for each stage. It also provides a model of the decision making process of the top management of a foreign unit of an MNC.

\section{Scope of the Paper}

A foreign unit of an MNC can be viewed as an organization which has to operate in the context of its strategic external environments of its host country, and its stakeholders. Both of these items may be viewed in a different perspective than what is viewed by the headquarters of the MNC. This is because the foreign unit executives are confronted with its host country environmental factors, and, these are not likely to feature as major factors in the ken of the headquarters.

The decision making process of the foreign unit's top management should focus upon:

(a) developing its strategy, (b) adapting or re-designing its structure, (c) cultivating the desired organizational culture, and (d) upgrading its technologies. In trying to focus on these, the top management must closely follow the expectations which its stakeholders place upon the unit. These expectations may change over time, and the unit's top 
management must modify its strategies as well.

The stage of organizational evolution of the foreign unit is also important to the top management in the choice of its future strategic directions. This approach of focusing upon the specific challenges and expectations of each stage in the evolution of the unit as an organization enables the top management to generate effective strategies. Each of the stages of evolution presents for the top management a three fold exercise: (a) performance expectations of the foreign unit, as set by the stakeholders, (b) criteria and dimensions for effective performance of the unit, as set by the stakeholders, and (c) the needed top management capabilities and traits.

\section{Discussions on Foreign Subsidiary Unit Evolution Process}

When the UK had its colonies and they had investors in the UK seeking good investment prospects in the then colonies, such as Canada, Australia, New Zealand, India. They had a system of managing agents in the UK's colonial countries with which they were more familiar than the investors than though many of the very investors had retired from the same colonial countries. The practice was then expanded to investors relying on the more intimate managing agents' knowledge of the workings of the companies in the UK itself than did the investors themselves. The concept and the practice of the agency theory became more widespread to some of other countries as well. It was a matter of trust that the investors displayed when the delegated the leveraging and re-directing the investments flows to the companies which they judged to be more sound investment. This approach subsequently became the concept and practice of diversified portfolios of the investors, devising a mix of investment targets depending upon the investors' need, such as those of safety of capital, growth, dividend and yield. The practice of the agency mechanism was able to create a wall between the investors and the companies into which their money was invested. A broader application of the managing agency concept is when the investors, stockholders and stock blockers who rely on the judgment of the top executive management in corporations.

Such explanations of the agency theory of the firm are found because there is the notion that the investors, stock brokers and stock analysts evaluate the performance of the top management and the results of the firm's financial and market performance. Thus, there is the perceived capability of the managing agents and the investment brokers that if the top managements of publically traded corporations do not perform according the stock market's expectations, the managing agents and the investors would withdraw the investments from the firm re-direct the flow of the investment capital to other investment targets with perceived better investment potentials. Such a potential threat would signal the workings of an active control system to the top managements of corporations. To further the agency argument, the investors would then rely on the top managements for an unspecified term, thereby entrusting them with the directions of the firm's activities. In this way, the top managements become the agents of the investors, managing agents and the stock brokers (Birkenshaw, Hood and Jonsson, 1998; Lala, 1993; O'Donnell, 2000; Roth \& O'Donnell, 1996; Reuer \& Miller, 1997; Roth \& Morrison, 1992). The close or distant relationship between the MNC corporate headquarters and the foreign subsidiaries would reflect the aforementioned managing agency theory and the expanded version the current times of the top management acting as agents of the investors and the stock brokers (Birkenshaw, 1996; Birkenshaw 1998; Birkenshaw, Hood and Jonsson, 1998; Rajagopalan \& Finkelstein, 1992; Tosi, Katz \& Gomez-Mejia, 1997; Zajac \& Westphal, 1995). An important issue for foreign subsidiaries in the local competitor environments that, in part, would shape the foreign subsidiaries' offensive and defensive competitor strategies, in ways consistent with expectations of the hierarchically upward impact on the top management, managing agents, stock brokers, and, subsequently, the investors (Miravitlles, Guitart-Tarrés and Nuñez-Carballosa, 2014).

During the momentous debate and vote in the UK regarding "Brexit" (i.e., whether or not Britain should exit from the European Union) one of the central issues was how much power should the centralized entity, the EU Parliament in Brussels, have over the UK internal affairs, as discussed by Bloomberg Businessweek, (2016), and Shuster, Simon, 2016. The contentious issue was how much control or power should a super entity like the EU has control over one of its 28 countries. The result of the June 23, 2016 vote is that the UK should get out of the EU. The frustration wrought out of the lack of self-determination feeling on the part of a majority of voting Britons regarding their internal affairs. A conservative Member of Parliament (MP), Craig Mackinlay remarked to Time contributor-author, Simon Shuster on the day of the Brexit vote, "I'm only half an MP, because half the decisions are made in Brussels". Shuster (2016) further observes that ".....the give-and-take between national sovereignty and European integration at the heart of the EU's debate over the benefits of 'an ever-closer union among the peoples of Europe'." (Shuster, 1016, 14) We may apply this tug-of-war to international business. An MNC's headquarters is like the super central entity, EU Parliament in Brussels, while the UK is like a foreign subsidiary unit. The pulls and push would typify the centrifugal and centripetal forces that show the dynamics of the MNC headquarters -foreign subsidiary unit 
relationship. One way to review the "correct balance" would be to hope for greater centralized (at MNC headquarters level) strategic coordination and decision-making, and, operational decentralization (at the foreign subsidiary unit level). From a proper perspective, good relationships among managers of an MNC headquarters and its foreign units are always desirable. Often foreign units' managers may get promoted to the headquarters. If so, they would have a better understanding of the subsidiary plight. It is vital to have a "we-are-in-this-together" feeling, bringing about greater unity and cooperativeness.

Studies of the foreign subsidiaries growth processes are a matter of interest to many scholars of international business, including Birkenshaw and Hood (1998). They have analyzed the process and directions of growth of foreign subsidiaries. They argue that, as foreign units deal with their local task environments, they change their strategic and operating scope usually in an incremental manner. For example, they may increase their own strategic initiatives, thereby widening and/or intensifying their own control over their strategic efforts. They may choose to widen their product range, expand the regional markets, increase their technological development, improve their supply chain, increase their capital projects, promote their products with greater vigor, or, retrench by doing the opposite activities. This approach would make them for decentralized, an action that is accelerated by their own resources self-reliance. The convers is true too. In this context, the degree of a foreign unit's resource self-reliance can be an important factor. Further, Birkenshaw and Hood (1998) explain the degree of control by the MNC headquarters over the foreign subsidiaries along three important characteristics. The important characteristics are: (a) the headquarters' driven strategic and operating initiatives (depending on their control desire, knowledge of local host country environments and the degree to which the subsidiary is depend on the headquarters' resources), (b) the subsidiary driven strategic initiatives (depending on their entrepreneurial capabilities and resource independence from the headquarters), and (c) the local host environment's factors.

A foreign subsidiary unit may continue doing the same scope of activities, i.e. continue with the same breadth and depth of its product lines, same processes, same equipment and other capital resources, same customer groups, same market regions, and same suppliers (Miravitlles, Guitart-Tarrés, and Nuñez-Carballosa, 2014). Such activities would indicate that their extant scopes of operations are stable and it has now intentions to create and pursue newer foreign subsidiary vision, mission and long term objectives.

Or, on the other hand, it could re-design its scope of activities, i.e. change (add and/or detract) its business and/or product portfolio, customer groups, suppliers, and enact newer markets. In this way, a foreign subsidiary would re-design its scope of activities. Such proactive initiatives would involve entrepreneurial endeavors. These would lead to revising its foreign subsidiary vision, mission, and long term objectives.

The top management of a foreign subsidiary unit develop its strategic and operating scope through their perception of: (a) the choices of the headquarters and the foreign unit, (b) the perception of local environmental (current and potential) opportunities and threats in the context of the foreign subsidiary unit's strategic and operating needs, and (c) the needs and expectations of the host country environment. The focus of a foreign subsidiary unit may shift from one project or problem to another in the context of the above strategic and operating decision making paradigm (Aggarwal \& Ramaswami, 1992; Galunic, 1996; Noda \& Bower, 1996; Poon, Kedron, and Bagchi-Sen, 2013). The continual assessment followed by the foreign unit depends upon the foreign unit's intra-organizational information evaluation, and based upon it, its re-evaluation of its existing policy. Growth of a foreign unit is predicated upon its resource acquiring capabilities, either on its own from its host country or from its headquarters. Its extant policy considerations should be further evaluated for its changing growth needs. Competitor information and market analyses would further its evaluation of strategic alternatives.

An MNC's capability to understand the changing and varying local conditions in its many foreign subsidiaries at best is limited. Examples abound in the literature about specific and detailed circumstances of host countries: (a) a US MNC headquarters might not know the detailed events that point to the direction, along with the reasons for it, of India's ruling party, the Bharatya Janata Party, which liberalized the economic scene (Karp, 2000); (b) a US pharmaceutical MNC headquarters might not know how to deal with the widespread violations of the rules of the World Trade Organization in Argentina by copying the specific patented drug formulations of US MNCs (Wall Street Journal, 2000).

Birkenshaw and Hood (1998) address the issue of a multinational subsidiary unit's evolution in the context of changing unit's scope. Other views on the subject can also be found from other scholars, e.g. Austin and Kohn (1991); Brewster and Pickard (1994); Filippov, Sergey, (2014); Galunic, D.C. 1996; Moskowitz (1992); Naisbitt (1994); Roth and Morrison, (1992); Roth and O'Donnell, (1998). They conclude that the process of foreign unit's organizational evolution and role are determined by: (a) the headquarters' imputing the role which they want the unit 
to pursue, (b) unit's own choice for itself (self determination), and (c) local environment determining the unit's role. Global business activities of an MNC are inextricably influenced by international politics (Saner, Yiu, Sondergaard, 2000). Local host country, regional and global politics can significantly affect organizational decision making and action. Business diplomacy and savvy are ways of displaying competence to the external environment and stakeholders (Austin and Kohn, 1991). There is a stronger argument to show wisdom of choice in its eclectic focus of strategic decision making, depending upon what constitutes to be critical issues for the stage in the evolution of a foreign unit.

The two approaches of economic and behavioral process view are both significant approaches of understanding the increasing internationalization of an MNC (Andersson, 2000). Three strategy types of MNC growth are here considered: (a) marketing entrepreneur, using international push strategy, (b) technical entrepreneur, using technical development so that the market would seek out its products, thus the international pull strategy, and (c) structure entrepreneur, using the strategy of international industry re-structuring.

The growth of an MNC with a focus on international market push strategy emphasizes the idea of analysis and targeting on specific market segments and geographical regions (Andersson, 2000). Push strategy is usually most needed during the first stages (see Table 2) of the foreign unit's organizational evolution in its host country environment. It is also needed to a somewhat lesser extent in stage two.

The technical-oriented pull strategy becomes most needed during the second stage of the foreign unit's evolution. It continues to be somewhat less critically needed during the third and fourth stage of the unit's evolution process. The structure-oriented strategy is critical in the fourth stage of the unit's evolutionary process.

\section{Top Management Decision Making Process}

This is a process by which a foreign unit assesses its strategic capabilities and makes a determination for its future strategic action. It has to evaluate the critical activities which it has to perform in each stage of the unit's evolutionary process. This makes it necessary for the top management to analyze the expectations of its stakeholders, which are listed in the top right part of the table. It also has to analyze the unit's current strategy, structure, organizational culture, and technology in the context of the current stage of its organizational evolution.

The top management should focus upon: (a) its expectation of performance, as set by its stakeholders, (b) the criteria of effective performance, as set by its stakeholders, and (c) its own capabilities and traits as a top management team. This process would enable the foreign unit's top management to determine the unit's future course of action.

\section{Organizational Life Cycle of an MNC's Foreign Subsidiary Unit}

When an MNC enters into a foreign country in the form of a (partially or wholly owned) foreign unit, then the foreign unit goes through phases of its organizational growth and evolution. These stages, as portrayed in Table 1, are very similar to the stages of an organization in starting up and growing in its own home country environment.

For each of the stages of its evolution in its host country, a foreign unit can expect differing challenges and expectations of performance by its stakeholders, which may include: MNC headquarters, unit employees, and host country's markets, governments, industry, suppliers and immediate communities in which the unit operates. These expectations span over issues such as: (a) expectations of unit's performance expectations, (b) criteria and dimensions for effective organizational performance, and (c) top management traits and capabilities.

There are expectations of events and activities at each of the four stages of evolution of the subsidiary unit. The four stages of a subsidiary unit are: (1) entrepreneurial, (2) collectivity, (3) formalization, and (4) elaboration. These stages are similar to the stages of evolution of a firm because they go through a similar process of evolution.

\subsection{Stage: Entrepreneurial or Start-Up Stage}

In the start-up stage the foreign unit performs similar activities as an organization starting up in its own domestic environment (Galunic, 1996). The major difference between the two is that a foreign subsidiary unit has received from its MNC headquarters proven business models, processes and organizational technologies, products and product designs, marketing methodologies and strategies, capital and management information and control systems, all of which are specific to the organization and line of business.

Nevertheless, a foreign unit starting up in a new country environment needs to do the same generic activities such as: choosing a specific marketable product, identifying specific market opportunity in the context of the host country environment. These are needed to be done because what may be a specifically appropriate product and market opportunity in the MNC's home country, or its other foreign units' host countries, may not be as specifically 
appropriate a product and market opportunity in the foreign unit's host environment.

The criteria for effective organizational performance are: survival of the foreign unit product adaptation and development to suit the local markets and applications, the development of service to satisfy the needs of its local constituents, and the initial establishment of the organization. The unit's top management would need to be more creative, problem solving, improvising its activities as it establishes its linkages with the various local sub-environments (in the process of forging its stakeholders). The greatest challenge for the top management of the foreign unit (after it established the foreign unit organization in its initial and basic form) is the effective marketing of its product, development of its local markets, establishing effective marketing channels, and establishing inter-organizational linkages (e.g. with banks, governments, unions, labor markets, supplier organizations).

To conclude, the start-up stage is the initial organizational formation stage that is marked by establishing its newly established physical presence in the context of the local nationals. Creativity, flexibility and marketing are the vital managerial activities in this stage.

Table 1. Organization life cycles of a foreign subsidiary unit and its performance expectations

\begin{tabular}{|c|c|c|c|c|}
\hline & $\begin{array}{c}\text { Stage } 1 \\
\text { Entrepreneurial } \\
\text { or Start-Up }\end{array}$ & $\begin{array}{c}\text { Stage } 2 \\
\text { Initial Growth \& } \\
\text { Organization }\end{array}$ & $\begin{array}{c}\text { Stage } 3 \\
\text { Formalization or } \\
\text { Larger Scale } \\
\text { Structuring }\end{array}$ & $\begin{array}{c}\text { Stage } 4 \\
\text { Sprawling Growth } \\
\text { and } \\
\text { Elaboration }\end{array}$ \\
\hline $\begin{array}{l}\text { Performance } \\
\text { expectations of the } \\
\text { foreign unit, as } \\
\text { perceived by } \\
\text { headquarters, host } \\
\text { country stakeholders }\end{array}$ & $\begin{array}{l}\text { Marketable product } \\
\text { Marketing } \\
\text { development } \\
\text { Profitable, } \\
\text { worthwhile market } \\
\text { opportunity, } \\
\text { Viable business } \\
\text { model for country }\end{array}$ & $\begin{array}{l}\text { Local Industry } \\
\text { recognition } \\
\text { Growth, rapid, } \\
\text { Knowing right } \\
\text { product range } \\
\text { \& application } \\
\text { Correct product, } \\
\text { service mix }\end{array}$ & $\begin{array}{l}\text { Internal stability } \\
\text { Needs, high } \\
\text { Mechanistic } \\
\text { Growth/ } \\
\text { Consolidation } \\
\text { Increased Staff } \\
\text { Formalization, } \\
\text { further }\end{array}$ & $\begin{array}{l}\text { Team approach } \\
\text { Reputation } \\
\text { Corporate image } \\
\text { Ethics } \\
\text { Social responsibility } \\
\text { Philanthropic } \\
\text { givings }\end{array}$ \\
\hline $\begin{array}{l}\text { Criteria and } \\
\text { dimensions for } \\
\text { effective } \\
\text { organizational } \\
\text { performance } \\
\text { Methods of } \\
\text { measuring } \\
\text { performance }\end{array}$ & $\begin{array}{l}\text { Survival } \\
\text { Product adaptation, } \\
\text { and development } \\
\text { Service development } \\
\text { establishment }\end{array}$ & $\begin{array}{l}\text { Vision, mission, } \\
\text { objectives, goals, } \\
\text { strategy } \\
\text { Benchmarking } \\
\text { Structuring the } \\
\text { organization } \\
\text { Identify product } \\
\text { depth \& width } \\
\text { Product range, } \\
\text { diversity }\end{array}$ & $\begin{array}{l}\text { Develop policies, } \\
\text { procedures } \\
\text { Organizational } \\
\text { efficiency } \\
\text { Technical } \\
\text { Innovativeness } \\
\text { Diversify product } \\
\text { Predictable behavior } \\
\text { and performance } \\
\text { from all people }\end{array}$ & $\begin{array}{l}\text { Defend your position } \\
\text { in industry } \\
\text { Don't lose market } \\
\text { share } \\
\text { Hold your own } \\
\text { Defend, defend, } \\
\text { defend } \\
\text { Intra-preneurial }\end{array}$ \\
\hline $\begin{array}{l}\text { Top management } \\
\text { traits \& } \\
\text { capabilities }\end{array}$ & $\begin{array}{l}\text { Creativity } \\
\text { Acquire and allocate } \\
\text { capital, Marketing } \\
\text { Promotion } \\
\text { Establish in market } \\
\text { place }\end{array}$ & $\begin{array}{l}\text { Manage capital } \\
\text { Manage growth } \\
\text { Effective } \\
\text { communication } \\
\text { Correct strategic } \\
\text { choices }\end{array}$ & $\begin{array}{l}\text { Mechanistic } \\
\text { atmosphere } \\
\text { Delegate authority } \\
\text { Professionalism } \\
\text { Standardization of } \\
\text { outcomes (expect) }\end{array}$ & $\begin{array}{l}\text { Decentralize } \\
\text { Autonomous units } \\
\text { Break organization } \\
\text { into smaller, } \\
\text { responsive units }\end{array}$ \\
\hline $\begin{array}{l}\text { Dominant } \\
\text { strategic focus, logic }\end{array}$ & $\begin{array}{l}\text { Entrepreneurial } \\
\text { marketer } \\
\text { Push strategy }\end{array}$ & $\begin{array}{l}\text { Entrepreneurial } \\
\text { marketer (Push) } \\
\text { Technical Marketer }\end{array}$ & $\begin{array}{l}\text { Technical and } \\
\text { structure } \\
\text { Strategy (Pull) }\end{array}$ & $\begin{array}{l}\text { Technical and } \\
\text { structure } \\
\text { Strategy }\end{array}$ \\
\hline
\end{tabular}

Description: Each stage has its own scenarios and circumstances which place upon the organization specific types of challenges (that are characteristic to that stage), and, to which the organization should respond to satisfy the criteria.

Source: Adapted from various sources, mainly Daft (2016). 


\subsection{Stage 2: Collectivity Stage}

Once the start-up stage that establishes the initial organization is completed, the foreign unit should focus on: (a) achieving a better and wider recognition from the local industry, (b) growth of sales units, (c) fine tuning of product design, attributes and applications, (d) revising product-mix, and (e) improving its organizational infrastructures for better organizational performance. The unit must be poised for growth.

The criteria and dimensions for effective organizational performance should focus upon better than adequate (or good) performance in the host country context. These would require good development of the unit's goals and vision that are concomitant with local aspirations and needs, bench marking activities and outcomes of the leaders in the region, setting of organic form of unit's organization, and re-defining the breadth and depth of product lines to better suit the market expectations and needs.

The challenges of the top management of the foreign unit are to: (a) manage growth in a systematic (as opposed to chaotic) manner, (b) allocate, manage and control capital which is infused from the MNC headquarters into the foreign unit during the growth and collectivity stage, (c) effective communication of its goals and strategies with its stakeholders, and (d) re-defining its strategic choices and strategic intent as it learns more about what the host environments, would prefer from the organization.

\subsection{Stage: Formalization or Large Scale Structuring Stage}

This stage is marked by building larger scale, rigid structures to perform highly standardized activities within departments. The organization's tasks are highly differentiated, and once differentiated, the specific activities are highly standardized with the intention of making them predictable, organized and performed as a routine through the use of policies and standard decision making process. The organization develops its internal organizational technology, and then seeks to buffer it from the dynamics of the external environments. The internal structure seeks stability as it manages to churn out a larger volume of activities to benefit from economies of scale.

The local, host country environment provides for enough throughput activities for the organization to perform with increasing efficiency. With increases in volume the unit seeks to increasingly automate (consistent with host government's policies regarding fuller employment of labor) and also to increase staff as it sets out to deal with increasing volume.

The criteria and dimensions for effective organizational performance are to ensure the continuity of organizational activities in a consistent manner. The unit should keep striving for organizational efficiency and technical innovativeness. The former is to reduce overhead cost per unit, and the later to increase market share.

With greater emphasis on consistency of organizational process, the focus on predictable outcomes becomes predominant. Growth and variations emanating from the external environment result in the organization seeking ways to regularize and systematize variability in order to make sense to the organization.

The challenge for the top management is to perpetuate bureaucracy and a mechanistic atmosphere. The result is that all strategic decision making is kept at the top level, while the middle and lower levels focus upon regular organizational activities. Professionalism and delegation of authority are ways to perpetuate bureaucracy. Professionalism is nurtured, and that is considered as the effective way to perpetuate the regularized organizational activities in order to ensure predictable outcomes.

The top management of the foreign unit has to generate a routine or "self-adaptive" organizational process which operates on an "auto pilot" approach, requiring only minimal attention from them. The near-mechanistic approach, with significant delegation of authority to the middle and lower management levels provides an efficient method of managing the organization.

\subsection{Stage 4: Sprawling Elaboration}

This stage is marked by rampant and rapid organizational expansion and growth to such an extent that the organization finds it challenging to maintain a semblance of order. Growth seems to march in all directions, and unchecked too. To cope with the rampant growth in size and scale of operations and increasing differentiation in the form of further "departmentation", the top management of the foreign subsidiary unit has to significantly break the organization into smaller, semi-autonomous sub-units and teams in order to make it more responsive to host country environmental challenges and changes. Management of change is a significant aspect of the continual adjusting and evolving process. This creation of the sub-unit and team as an approach is effective in engendering internal process changes, and it leads to organizational continually adjusting to the external changes, if not significantly re-inventing 
itself in the process. The emphasis would be to focus upon good organizational ethics and to project a good corporate image to the host country community.

The top management of the foreign unit is expected to set a higher level of expectations for its own conduct in particular, and, in the way the organization deals with its local constituencies. Its credo has to be "growth with ethics" and it should establish good relationships with all influential individuals and groups with all important external environmental segments (e.g. political groups, industrialists, bankers, suppliers, unions, and governmental agencies, companies in the same and other allied industries, local communities and cities).

The criteria and dimensions for effective organizational performance in this stage focus upon holding the foreign unit's market position. It has to defend its market share by developing marketing strategies to consolidate its market performance. Its strategies would include internal entrepreneurial (intra-preneurial) approach to reinvent the organization in order to re-generate and innovate its internal motivational climate and organizational activities.

The top management traits and capabilities include a continuation of the decentralization which was a major trend in the previous stage. The now larger organization needs to adapt to changing organizational activities in its attempt to effectively respond to changing environmental challenges. The organizational response would mainly focus upon rapid internal assessment and proactive response to varying external challenges.

This is better done through a more organic, or internal evolutionary, mode of organization. Thus, what is called for is a smaller decision making body of people who are: (a) empowered to make the decision, (b) possessing skills, knowledge and details needed to make the decision, (c) good in communicating to all parts of the organization, (d) good at inter-organizational linkages, and (e) good at focusing on the core technology and basic mission of the organization.

Global competitor analysis may be the purview of the MNC headquarters for it is an overall corporate concern. Strategic management of the overall vision, mission, and long term objectives wrought through formal and systematic process should be the purview of the MNC headquarters through such activities of strategic analyses. The gathering and analysis of information should be done in conjunction with the foreign subsidiary units. Strategic action should involve all executives of the entire organization, including those of the foreign subsidiary units. The foreign units must be integrated into the process. MNC headquarters may thus focus on the MNC vision, mission, long term objectives, and major strategies. There should healthy cooperation, integration, and involvement among all executives across the entire breadth of the MNC organization.

\section{Conclusions}

The strategic focus varies with organizational challenges, and, the rate of change and the degree of complexity of the organizational environments. It depends upon the organizational response to the strategic variables inside and outside of the organization. The stage of the organization evolution is critical to the choice of the top management capabilities and traits, and, the kinds of organizational performance that are expected of the organization.

Strategic management of the overall MNC must be performed by all executives of the MNC for it to be continuously competitive. Strategic data gathering and analyses for all strategic issues would involve active cooperation from all foreign units. Overall organizational strategic decision making and action would be the concern of all of the MNC organization; the foreign subsidiary units must be fully involved.

The management of the foreign subsidiary unit would do well to review its on-going performance trends and review its changing expectations in light of the headquarters' changing key success criteria, views and performance metrics. It must also strive to exceed the major expectations of the sets of stakeholders, one at the headquarters level and the other, at the foreign subsidiary level, and in doing so it would meet the simultaneously oversight from both levels.,

The organizational life cycle stage of a foreign subsidiary unit significantly determines: (a) a foreign unit's performance expectations, (b) criteria and dimensions for effective organizational performance, and (c) top management traits and capabilities. An MNC must choose correctly its dominant strategic logic, based upon its current life cycle stage. The four stages are: (1) entrepreneurial or start-up stage, (2) growth and collectivity stage, (3) formalization stage, and (4) sprawling elaboration stage. Each stage has its own challenges and uniqueness. A foreign subsidiary must identify its stage and choose its activities within the construct of the stage.

The top management of a foreign unit must correctly assess the opportunities and threats of each stage, and appropriately respond to the needs of the organization in the particular stage, and satisfy the expectations of the stakeholders of the foreign unit. Organizational growth and evolution of a foreign unit may be more smooth and 
better facilitated if the unit is correctly navigated through the stages. The vision and skills of the top management are critical to the process.

\section{References}

Aggarwal, S., \& Ramaswami, S. (1992). Choice of foreign market entry mode: Impact of ownership, location and international factors. Journal of International Business Studies, (23), 1-28. http://dx.doi.org/10.1057/palgrave.jibs. 8490257

Andersson, Svante. (2000). The internationalization of the firm from an entrepreneurial perspective. International Studies of Management and Organization, 30(1), Spring, 63-92. http://dx.doi.org/10.1080/00208825.2000.11656783

Austin, James E., \& Thomas, O. Kohn. (1991). Strategic Planning in Developing Countries. New York, NY: Free Press.

Birkenshaw, Julian. (1996). How multinational subsidiary mandates are gained and lost. Journal of International Business Studies, (27), 467-495. http://dx.doi.org/10.1057/palgrave.jibs.8490845

Birkenshaw, Julian, \& Neil Hood. (1998). Multinational subsidiary evolution: Capability and charter change in foreign-owned subsidiary companies. Academy of Management Review, 23(4), 773-795.

Birkenshaw, Julian, Hood, N., \& Jonsson, S. (1998). Building firm-specific advantages in multinational corporations: The role of subsidiary initiative. Strategic Management Journal, 19(3), 221-241. http://dx.doi.org/10.1002/(SICI)1097-0266(199803)19:3<221::AID-SMJ948>3.0.CO;2-P

Bloomberg Businessweek. (2016). After Brexit, here's what next for Europe. July 4-10, 8-13.

Brewster, C., \& Juana, P. (1994). Evaluating training. International Studies of Management and Organization, 24(2), 18-36. http://dx.doi.org/10.1080/00208825.1994.11656635

Draft, R, L. (2016). Organization Theory and Design (12 ed.). South-Western/Cengage-Learning.

Filippov, S. (2014, November). Knowledge-sharing subsidiaries in Central and Eastern Europe. Europe-Asia Studies, 66(9), 1553-1571. http://dx.doi.org/10.1080/09668136.2014.956442

Galunic, D.C. (1996). Recreating divisional domains: Intra-corporate evolution and multi-business firm. In B. Keys and L.N. Dosier, (Eds.), Proceedings of the Academy of Management, 219-224. http://dx.doi.org/10.5465/AMBPP.1996.4980454

Karp, J. (2000). Reform Raj: India regains investors' confidence. The Wall Street Journal, February 8, A10-12.

Lala, R.M. (1993). Beyond the Last Blue Mountain. India: Penguin Book.

Lim, Ngat-Chin, Edwards, Ron, \& Tee, Ding-Ding. (2015, Jan-March). Reshaping Malaysian subsidiaries in the wake of China's rise as the preferred location for foreign production. Journal of Asia-Pacific Business, 16(1), 66-87. http://dx.doi.org/10.1080/10599231.2015.997627

Miravitlles, Paloma, Guitart-Tarrés, Laura, \& Nuñez-Carballosa, Ana. (2014). Competitiveness of Spanish foreign subsidiaries. Competitiveness Review, 24(3), 171-189. http://dx.doi.org/10.1108/CR-05-2013-0050

Moskowitz, D. B. (1992). How to cut it overseas. International Business, 5(10), 76-78.

Naisbitt, J. (1994). Global Paradox. New York, NY: William \& Morrow.

Noda, T., \& Bower, J.L. (1996). Strategy making as iterated process of resource allocation. Strategic Management Journal, 17, 159-192. http://dx.doi.org/10.1002/smj.4250171011

O’Donnell, Sharon W. 2000. Managing foreign subsidiaries: Agents of headquarters, or an independent network. Strategic Management Journal, 21, 251-548.

Poon, Jessie P.H., Kedron, Peter, \& Bagchi-Sen, Sharmistha. (2013, October). Do foreign subsidiaries innovate and perform better in a cluster? A spatial analysis of Japanese subsidiaries in the US. Applied Geography, 44, 33-42. http://dx.doi.org/10.1016/j.apgeog.2013.07.007

Rajagopalan, N., \& S. Finkelstein. (1992). Effects of strategic orientation and environmental change on senior management reward systems. Strategic Management Journal, 13, 127-142. http://dx.doi.org/10.1002/smj.4250131010

Raziq, Muhammad Mustafa, Borini, Felipe Mendes, Perry, Martin, \& Battisti, Martina. (2013). Subsidiary 
characteristics and impact on subsidiary strategic and operational autonomy. Journal of Transnational Management, 18(3), 219-241. http://dx.doi.org/10.1080/15475778.2013.817271

Roth, K., \& A.J. Morrison. (1992). Implementing global strategies: Characteristics of global subsidiary mandates. Journal of International Business Studies, 23, 715-735. http://dx.doi.org/10.1057/palgrave.jibs.8490285

Roth, K., \& S. O'Donnell. (1996). Foreign subsidiary compensation strategy: An agency theory perspective. Academy of Management Journal, 39, 678-703. http://dx.doi.org/10.2307/256659

Saner, Raymond, Lichia Yiu \& Mikael Sondergaard. (2000). Business diplomacy management: A core competency for global companies. Academy of Management Executive, 14(1), 80-92. http://dx.doi.org/10.5465/ame.2000.2909841

Shuster, Simon. (2016). Special Report: Europe's crisis of faith. Time, July 11-July 18, 11-21.

The Wall Street Journal. (2000). Daley warns Argentina on royalties, February 20, A-11.

Time. (2001). Changes at Nissan. January 21, 42-46.

Tosi, H.L., J.P. Katz, \& L.R. Gomez-Meji. (1997). Disaggregating the agency contract: The effects of monitoring, incentive alignment, and term in office on agent decision making. Academy of Management Journal, 40, 584-602. http://dx.doi.org/10.2307/257054

Zajac, E.J., \& J.D. Westphal. (1995). Accounting for the explanations of CEO compensations: Substance and explanations. Administrative Science Quarterly, 40, 283-308. http://dx.doi.org/10.2307/2393639 